\title{
UPAYA MENINGKATKAN HASIL BELAJAR EKONOMI DENGAN MENGGUNAKAN MEDIA AUDIO VISUAL PADA PESERTA DIDIK KELAS XI MA MIFTAHUL JANNAH PALANGKA RAYA
}

\author{
Trisnawati $^{1}$, M. Andi Setiawan ${ }^{2}$
}

email: andiysetiawan@gmail.com

\begin{abstract}
This study aims to determine the Improvement of Learning Outcomes and Learning Activities of Class XI students of Madrasah Aliyah Miftahul Jannah Palangakaraya using audio visual media. The type of research used in this study is Classroom Action Research (CAR). The instruments of data collection in this study were observation and tests. While the data analysis techniques in this study used the classical and individual completeness percentage formula. The results of the study: (1) Learner Activities Learning Madrasah Aliyah class XI Miftahul Jannah Palangkaraya at the time of economic learning using audio visual media is more active, (2) There is an increase in learning outcomes of students of class XI Economics Madrasah Aliyah Miftahul Jannah Palangkaraya after using Audio Visual Media.
\end{abstract}

(C) Muhammadiyah University of Palangkaraya

Keywords: Results of learning economics and audio visual media

\begin{abstract}
ABSTRAK
Penelitian ini bertujuan untuk mengetahui Peningkatan Hasil Belajar dan Aktifitas belajar siswa Kelas XI Madrasah Aliyah Miftahul Jannah Palangakaraya menggunakan media audio visual. Jenis penelitian yang digunakan dalam penelitian ini adalah Penelitian Tindakan Kelas (PTK). Instrumen pengumpulan data dalam penelitian ini adalah observasi dan tes. Sedangkan teknik analisis data dalam penelitian ini menggunakan rumus persentase ketuntasan klasikal dan individu. Hasil penelitian: (1) Kegiatan Pembelajar Pembelajar Madrasah Aliyah kelas XI Miftahul Jannah Palangkaraya pada saat pembelajaran Ekonomi menggunakan media audio visual lebih aktif, (2) Ada peningkatan hasil belajar siswa kelas XI Ekonomi Madrasah Aliyah Miftahul Jannah Palangkaraya setelah menggunakan Audio Visual Media.
\end{abstract}

(C) Universitas Muhammadiyah Palangkaraya

Kata Kunci: Hasil belajar ekonomi dan media audio visual

Trisnawati $^{1}$ Universitas Muhammadiyah Palangkaraya 


\section{PENDAHULUAN}

Pendidikan merupakan suatu hal yang sangat penting dan tidak dapat dipisahkan dari kehidupan seseorang baik dalam keluarga, masyarakat dan bangsa. Negara Indonesia sebagai Negara yang berkembang dalam pembangunan membutuhkan sumber daya manusia berkualitas yang dapat diandalkan. Salah satu usaha menciptakan sumber daya manusia berkualitas yang dapat diandalkan adalah melalui pendidikan. Sekolah sebagai salah satu pendidikan formal memiliki peranan yang sangat penting dalam mewujudkan tujuan pendidikan nasional melalui proses belajar mengajar.

Undang-Undang No. 20 Tahun 2003 pasal 3, telah digariskan bahwa: Pendidikan nasional bertujuan mencerdaskan bangsa dari mengembangkan manusia Indonesia seutuhnya, yaitu manusia yang beriman dan bertaqwa terhadap Tuhan Yang Maha Esa dan berbudi pekerti luhur, memiliki pengetahuan dan ketrampilan, kesehatan jasmani dan rohani, kepribadian yang mantap dan mandiri serta rasa tanggung jawab kemasyarakatan dan kebangsaan. (Undang- Undang No.20 tahun 2003).

M. Andi Setiwan (2017: 21) Pembelajaran pada dasarnya adalah proses yang dilakukan individu dengan bantuanguru untuk memperoleh perubahan perilaku menuju pendewasaan diri secara menyeleuruh.

Adakalanya penerima pesan (peserta didik) benar dalam menafsirkan pesan yang disampaikan oleh guru, tapi adakalanya mereka salah dalam menafsirkan. Ada beberapa faktor yang menjadi penghambat komunikasi, diantaranya hambatan psikologis, hambatan lingkungan, dan hambatan kultural.

Pembelajaran lebih menarik jika ada perpaduan tepat antara pemilihan metode pembelajaran dengan media yang digunakan. Seiring dengan berkembangnya teknologi informasi dan komunikasi (TIK), mengharuskan dunia pendidikan untuk menerapkan pembelajaran berbasis komputer. Guru harus dapat mencitakan suatu pembelajaran yang berpotensi menciptakan suasana belajar mandiri, serta membawa kelas bagaikan magnet yang mampu menikmati dan menarik peserta didik untuk belajar dalam suasana yang menyenangkan, salah satunya dengan memanfaatkan vidio pembelajaran yang bersifat tutorial (membimbing).

Azhar Arsyad (2007:36) Interaktif vidio adalah suatu sistem penyampaian pengajaran dimana materi vidio rekaman disajikan dengan mengendalikan komputer kepada penonton (peserta didik) yang tidak hanya mendengar dan melihat vidio dan suara, tetapi juga memberikan respons yang aktif, dan respon itu yang menentukan kecepatan dan sekuensi.

Hasil dari kajian awal yang dilakukan oleh peneliti di MA Miftahul Jannah Palangkaraya pada kelas XI, bahwa adanya masalah dalam proses pembelajaran yang dilakukan oleh guru seperti proses pembelajaran yang monoton, guru masih menggunakan metode ceramah, dan penggunaan media yang kurang. kemudian dari 
pengamatan terhadap peserta didik ditemukan adanya kurangnya partisipasi peserta didik dalam proses pembelajaran terlihat dari jarangnya peserta didik yang bertanya, masih rendahnya nilai peserta didik pada mata pelajaran ekonomi sehingga kurangnya memperhatikan materi yang dijelaskan oleh guru.

Dengan demikian dalam proses belajar mengajar yang yang menarik agar proses pembelajaran tidak hanya satu arah dimana fungsi pengajaran yang lebih dominan dan peserta didik tidak hanya mendengarkan, sehingga dalam penelitian ini mencoba memilih media audio visual yang berupa video agar peserta didik bisa lebih aktif dalm proses pembelajaran. Sugihartono, (2007:76-77), menyebutkan faktorfaktor yang mempengaruhi hasil belajar sebagai berikut:

1. Faktor internal, adalah faktor yang ada dalam diri individu yang sedangbelajar. Faktor internal meliputi: faktor jasmaniah dan psikologis.

2. Faktor eksternal, adalah faktor yang ada diluar individ. Faktor eksternal meliputi: faktor keluarga, faktor sekolah, dan faktor masayarakat.

Menurut Daryanto (2011:79) mengemukakan beberapa kelebihan penggunaan media vidio, antara lain:

1. Video menambah satu dimensi baru di dalam pembelajaran, video menyajikan gambar bergerak kepada siswa disamping suara yang menyertainya.

2. Video dapat menampilkan suatu fenomena yang sulit untuk dilihat secara nyata

\section{METODE PENELITIAN}

Penelitian menggunakan Penelitian Tindakan Kelas (PTK), yang dilakukan oleh peneliti secara langsung. Penelitian Tindakan Kelas (PTK) menuntut peneliti untuk terlibat langsung dalam penelitian yang dilakukan peneliti. Peneliti terlibat langsung dalam setiap kegiatan penelitian yang dilakukan oleh peneliti agar mendapat data yang akurat. Peneliti harus turun langsung setiap kali proses pengumpulan data dilapangan seperti laporan observasi dan tes.

Subjek penelitian adalah orang atau benda yang akan diteliti yaitu, peserta didik kelas XI, yang diobservasi semua peserta didik kelas XI dan yang di tes semua peserta didik kelas XI, subjek yang dibutuhkan dalam penelitian ini adalah kelas XI dengan jumlah 18 peserta didik di MA Miftahul Jannah Palangka Raya.

Observasi dalam penelitian ini untuk pengumpulan data awal permasalahan dalam penelitian dan dilakukan oleh 2 observer sebagai pengamat I (guru kelas) dan pengamat II (teman sejawat) dalam melihat aktivitas guru, aktivitas peserta didik dan proses pembelajaran.

Tes merupakan pengukuran kemampuan yang dicapai oleh peserta didik setelah diberi proses pembelajaran. Jadi, tes dalam penelitian ini berupa soal pilihan ganda pada materi pasar modal yang bertujuan untuk mengetahui kemampuan peserta didik dalam menerima pelajaran yang diberikan oleh guru. 
Data kuantitatif berasal dari post tes yang dilakukan diakhir pertemuan. Hal ini dilakukan untuk mengetahui peningkatan hasil belajar dan keaktifan bertanya peserta didik dalam pembelajaran.

Data kualitatif diperoleh dari hasil observasi dimaksudkan untuk mengetahui kekurangan dan kelbihan dari pembelajaran yang dilakukan, data kualitatif diperoleh dari aktifitas peserta didik dan guru dalam proses pembelajaran yaitu dengan cara menganalisis keaktifitan bertanya peserta didik dan keefektifan pembelajaran yang dilakukan guru dengan menggunakan media audio visual berupa video.

\section{HASIL DAN PEMBAHASAN}

Pada tahap ini peneliti melaksanakan tindakan pembelajaran pada mata pelajaran ekonomi menggunakan media Audio Visual pada peserta didik kelas XI MA JANNAH Palangka Raya.

Pengamatan observasi guru dan aktivitas peserta didik, observasi guru dan aktivitas peserta didik pada siklus I dan siklus II dapat dilihat pada gambar berikut:

\section{Gambar 1}

Grafik Aktivitas Guru dan Peserta Didik

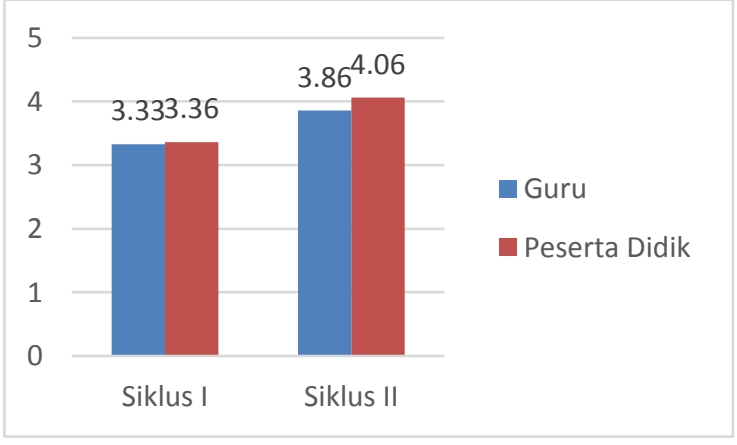

Pada tahap awal di saat observasi sebelum menerapkan siklus I dan siklus II dengan meggunakan mdia audio visual berupa video hasil belajar peserta didik masih rendah. Namun ketika diterapkan pada siklus I aktivitas belajar peserta didik dari 18 siswa rata-rata hasil pengamatan aktivitas yaitu $3,36 \%$ terdapat dan pada siklus II dari 18 peserta didik rata-rata pengamatan hasil aktivitas meningkat menjadi 4,06\%. Hasil belajar peserta didik yang perhitungannya didapat dari penilaian hasil post test siklus I dengan hasil persentase $72 \%$ dan post tes siklus II dengan hasil $100 \%$ yang terdapat peningkatan hasil belajar dari siklus I dan II.

\section{KESIMPULAN}

Berdasarkan pengamatan yang dilakukan oleh dua pengamat hasil aktivitas peserta didik selama pembelajaran ekonomi dengan menggunakan media audio visual berupa video pembelajaran pada siklus I dan II menjadi lebih aktif. Pada siklus I memperoleh skor 3,36 dengan kategori baik dan pada siklus II mengalami peningkatan menjadi 4,06 dengan kategori baik.

Hasil belajar peserta didik kelas XI MA Miftahul Jannah Palangka Raya dengan menggunakan media audio visual mengalami peningkatan dari data awal rata-rata 63,88 dan ketuntasan secara klasikal $11 \%$. Nilai rata- rata pada siklus I 76,11 dan ktuntasan secara klasikal $72 \%$. Nilai rata-rata pada siklus II 85,27 dengan ktuntasan klasikal 100\%. 
BITNET Jurnal Pendidikan Teknologi Informasi, Februari 2018, Volume 3 Nomor 1 (29-33) http://journal.umpalangkaraya.ac.id/index.php/bitnet

DAFTAR PUSTAKA

Arsyad, Azhar (2011), Media Pembelajaran. Jakarta: PT. Raja Gravindo Persada.

Daryanto. (2010). Media Pembelajaran, Yogyakarta: Gava Media.
M. Andi Setiawan. 2017. Belajar dan Pembelajaran. Ponorogo: Uwais Inspirasi Indonesia

Sugihartono (2007), Psikologi Pendidikan.Yogyakarta: UNY. 